\title{
From Allergy to Schistosomes: Role of Fc Receptors and Adhesion Molecules in Eosinophil Effector Function
}

\author{
Sophie Nutten, François Trottein, Abdelillah Soussi Gounni, Jean-Paul Papin, \\ André Capron, Monique Capron ${ }^{+}$
}

Centre d'Immunologie et de Biologie Parasitaire, Unité INSERM 167, Institut Pasteur, 1 rue du Professeur A. Calmette, 59019 Lille Cédex, France

The dual function of eosinophils has been evidenced in protective immunity against parasites as well as in pathological manifestations during allergic disorders. We have demonstrated that a new class of IgE receptors, FcERII/CD23, was involved in the functional duality of eosinophils and other proinflammatory cells. More recently, we have shown that FcERI, the high affinity IgE receptor thought to be only expressed by basophils and mast cells, was involved in eosinophil-mediated cytotoxicity against schistosomes as well as in mediator release. These results favour the view that both IgE and its receptors have been primarily associated to a protective immune response, rather than to pathology. Not only IgE receptors but also members belonging to the family of adhesion molecules can participate as co-receptors in eosinophil effector function. The inhibitory role of monoclonal antibodies to Lewis $X$ $\left(L e^{X}, C D 15\right)$ or to selectins in eosinophil-mediated cytotoxicity towards schistosomes and the detection of $L e^{X}$ and 'selectin-like' molecules on schistosomula surface indicate a double interaction mediated by selectins and their carbohydrate ligands between eosinophils and schistosomula. These results suggest new functions for these adhesion molecules, previously known to be involved mainly in cell infiltration.

Key words : eosinophils - schistosomes - allergy - Fc receptors - adhesion molecules

Eosinophils exert a functional duality, participating both in protective immune response during parasitic infections and in the induction of cell and tissue damage, specially in allergic manifestations. One of the best known functions of eosinophils is certainly their cytotoxic potential for schistosome targets, evidenced in vitro as well as in vivo. In the presence of different antibody isotypes, including subclasses of $\operatorname{IgG}, \operatorname{IgE}$ and $\operatorname{Ig} \mathrm{A}$, eosinophils can kill young larvae of Schistosoma mansoni, according to a process of antibody-dependent cell-mediated cytotoxicity (ADCC). This mechanism requires several successive steps, namely recognition of targets by antibodies, adhesion of cells to parasites and release of cytolytic mediators. Some similarities have been evoked to explain the pathological potential of eosinophils in allergy. In particular, the detection of the same antibody classes or subclasses on the surface of eosinophils from allergic patients, associated to the presence of cytotoxic granule proteins at the sites of allergic inflammation, suggest a process of antibody-mediated degranulation. During the recent years, we

\footnotetext{
${ }^{+}$Corresponding author. Fax: +33-3-2087.7888. E.maill: monique.capron@pasteur-lille.fr Received 3 September 1997 Accepted 30 September 1997
}

have particularly investigated the nature of the membrane receptors involved in eosinophil activation, pointing to the major role played by $\operatorname{IgE}$ receptors. More recently, we have shown that additional receptors, known to allow eosinophil adherence to endothelial cells and belonging to various adhesion receptor families were also involved in the cytotoxic properties of eosinophils.

In the present review, we will discuss the interactions between eosinophils and $\mathrm{IgE}$, through low and high affinity Fc receptors for IgE, as well as recent results showing that adhesion molecules of the selectin family and their carbohydrate ligands, expressed both by eosinophils and by schistosome targets, are involved in cytotoxicity and activation of eosinophils. Taken together, these results illustrate novel molecular interactions potentially involved in the dual function of eosinophils, in protection against parasites as well as in allergy and in inflammation.

\section{EOSINOPHILS AND LOW AFFINITY IgE RECEPTOR (FCERII/CD23)}

$\operatorname{IgE}$ receptors have been first characterized on human eosinophils by binding assays (IgE rosette formation, binding of radiolabelled $\mathrm{IgE}$ and flow cytometry analysis) as well as by functional assays (Capron et al. 1981, 1984). Eosinophil IgE receptors are involved in IgE-mediated immune responses including cytotoxicity against parasites 
and allergy (Capron et al. 1984, 1986, 1991). The inhibitory effects of polyclonal and monoclonal antibodies (mAbs) against the low affinity receptor FceRII/CD23 on the IgE-dependent functions of eosinophils first indicated that eosinophils could express this receptor (Capron et al. 1986, 1991, Capron A et al. 1986). Flow cytometry analysis revealed indeed that CD23 was expressed on human eosinophils, with a large variability according to individual patients (Capron et al. 1991). Various biochemical procedures indicated some common characteristics between eosinophil FcERII and CD23 (Jouault et al. 1988, Grangette et al. 1989). More recently, we have added molecular data to confirm the synthesis of CD23 by eosinophils and to support the hypothesis of identity between eosinophil FceRII and B cell CD23 (Soussi Gounni et al. manuscript in preparation). In situ hybridization confirmed the presence of CD23 mRNA in purified eosinophils. Using polymerase chain reaction of reverse-transcribed total RNA (RT-PCR) procedure, the sequence of human eosinophil cDNA derived from a cDNA library revealed a total homology with the two isoforms of CD23, namely CD23 "a" and CD23 "b". Moreover, RT-PCR analysis showed that eosinophils from different hypereosinophilic patients expressed both CD23 "a" and "b" isoforms. In situ RT-PCR confirmed that mRNA corresponding to CD23 "a" and " $b$ " isoforms is detected in cytocentrifuged preparations of purified eosinophils. Finally, immunocytochemistry allowed us to confirm the presence of CD23 protein in eosinophils with a variable expression according to individual patients.

Taken together, these results provide the first evidence that the low affinity receptor for IgE, synthesized by human eosinophils, is identical to the CD23 molecule expressed on B cells. The two species of CD23 "a" and "b", differing by a short sequence in their intracytoplasmic domain, appeared to differ in their cellular distribution and function: CD23 " $a$ " being associated to IgE-dependent endocytosis and CD23 "b" rather involved in IgEmediated phagocytosis (Yokota et al. 1988). It has been previously reported that the Eo L3 cell line, a so-called "eosinophilic" cell line, exclusively expressed the CD23 "b" isoform (Yokota et al. 1988), suggesting therefore that only CD23 "b" could be detected in eosinophils, an hypothesis not confirmed by our results. On the basis of the different role of the two isoforms of CD23, the present findings, showing that eosinophils could express both CD23 "a" and "b", imply that CD23 could participate in various functions of eosinophils, including antigen presentation. This first example illustrates that findings obtained from studies on parasite immunity can provide new insights into general functions of eosinophils in immune response.

\section{EOSINOPHILS AND HIGH AFFINITY IgE RECEPTOR (FCERI)}

After the description of CD23 on human eosinophils, we have investigated the existence of other IgE-binding molecules. Recently, Mac2/ع-binding protein, a molecule belonging to the S-type lectin family, was detected on human eosinophils (Truong et al. 1993). Inhibition of IgE-binding and IgEmediated cytotoxicity towards parasites by antiMac2 antibodies indicated the functional role of such molecules in IgE-associated diseases. A role of FceRI was not initially evoked since this receptor was reputed to be solely expressed on mast cells and basophils (Ravetch \& Kinet 1991). The demonstration that FceRI is present on Langerhans cells in the skin (Wang et al. 1992) suggested that it might be expressed by other immune effector cells. Anti-FceRI $\alpha$ chain mAbs were used to investigate the surface expression of FceRI $\alpha$ chain on human eosinophils from patients with hypereosinophilic syndromes. By flow cytometry, positive staining was detected on $13 \%$ to $73 \%$ of eosinophils from individual donors. These results indicate that in contrast to mast cells, which constitutively express FceRI, expression of FceRI by blood eosinophils was variable among patients (Soussi Gounni et al. 1994).

The $\alpha$ chain of the high-affinity receptor is known to contain the binding site for IgE. To examine the expression of mRNA corresponding to the $\alpha$ chain of the FceRI receptor by eosinophils, Northern blot was performed with a cDNA probe coding for the human $\alpha$ chain of FceRI. RNA extracts from eosinophils of all patients tested produced a signal at $1.2 \mathrm{~Kb}$, but with varying intensity among individual patients. The question of whether eosinophils could express $\beta$ and $\gamma$ chains remained open. Because of the limited quantity of highly purified eosinophils, the analysis was done by RT-PCR. The amplification products obtained from highly purified eosinophils revealed the predicted band for the FceRI $\beta$ chain and the $\gamma$ chain. Our studies provide the first evidence that eosinophils express the three components of the high-affinity IgE receptor FceRI. Consequently, we attempted to determine whether FceRI is involved in the cytotoxicity of eosinophils against parasites. For this purpose, purified eosinophils, schistosomula targets and IgE antibody-containing immune serum samples were incubated in the presence of a mAb directed against the $\alpha$ chain of FceRI (mAb 15-1). A dose-dependent inhibition of cytotoxicity was observed with mAb 15-1 but not with the isotype control mAb (Soussi Gounni et al. 1994). 
Since we had previously shown that eosinophils from allergic patients could selectively release eosinophil peroxidase (EPO) but not eosinophil cationic protein (ECP), two basic proteins contained in eosinophil granules, in an IgE-dependent manner (Tomassini et al. 1991), we have investigated the role of FceRI in this mechanism. Highly significant levels of EPO were detected after crosslinking of FceRI with mAb 15-1 and anti-mouse antibodies as second antibodies. In contrast, no significant release of ECP was obtained in the same conditions, confirming our hypothesis of eosinophil selective degranulation. These findings indicate that involvement of FceRI drives the same signal to induce mediator release that $\mathrm{IgE}$ immune complexes and suggest that FceRI could be implicated in IgE-dependent eosinophil activation (Soussi Gounni et al. 1994).

The results of this study indicate a so far unsuspected function for FceRI in IgE-dependent anti-parasite immune defense in addition to its role in allergic manifestations. These results therefore suggest that not only $\operatorname{IgE}$ and the low-affinity $\operatorname{IgE}$ receptor, but also the high-affinity $\operatorname{IgE}$ receptor, have probably appeared during evolution to protect organisms against pathogens rather than to induce pathologic allergic reactions. Although the precise interactions between the different types of IgE-binding molecules remain to be elucidated, their expression on eosinophil membranes and on the other proinflammatory cells reinforces the dual function of these cell populations in both immune defense and diseases.

ROLE OF ADHESION MOLECULES IN EOSINOPHIL EFFECTOR FUNCTION AGAINST SCHISTOSOME

In mammals, several families of adhesion molecules including integrins, members of the immunoglobulin superfamily (IgSF), selectins, cadherins and sialomucins mediate cell-cell adhesion and signal transduction (Carlos \& Harlan 1994). Among them, selectins belong to the superfamily of calcium-dependent lectins (C-type lectins) and consist of three homologous members expressed on activated platelets (P-selectin), activated endothelial cells (P- and E-selectins) and on leukocytes (L-selectin) (Bevilacqua \& Nelson 1993). They are involved in lymphocyte homing, in leukocyteplatelet interactions and in inflammatory responses by initiating the extravasation of leukocytes through vascular endothelium. They recognize cellsurface carbohydrates including multivalent forms of sialylated, fucosylated and sometimes sulfated lactosaminoglycans such as the sialyl Lewis ${ }^{\mathrm{X}}$ tetrasaccharide (sLe ${ }^{X}$ : NeuNAc $\alpha 2-3$ Gal $\beta 1-4$ [Fuc $\alpha$ 1-3] GlcNAc, sCD15) and, to a lesser extent, the unsialylated $\mathrm{Le}^{\mathrm{X}}$ determinant (Larsen et al. 1990,
Rosen \& Bertozzi 1994, Kansas 1996).

Eosinophils express a wide array of adhesion molecules including $\beta 1$ and $\beta 2$ integrins (VLA-4, LFA-1, Mac-1), IgSF members (such as ICAM1), L-selectin and carbohydrate ligands for selectins (Le ${ }^{X}$-related structures) (Bochner et al. 1994). These molecules are critical for eosinophil adhesion to activated vascular endothelium and epithelium, for eosinophil migration and tissue localization and are also implicated in various functions such as eosinophil activation (Schleimer et al 1992). The cytotoxic properties of eosinophils against parasite targets have been extensively studied, not only in vitro but also in vivo. It has been shown, for instance, that ADCC mediated by eosinophils required different steps, including a phase of reversible adherence followed by an irreversible adherence phase (Butterworth et al. 1979). Since some adhesion molecules, such as LFA 1, have been described as accessory molecules involved in the step of adherence between cytotoxic $\mathrm{T}$ cells and their tumoral targets (Springer 1990), we suspected that they could also play a role in eosinophil-dependent cytotoxicity against schistosomula of $S$. mansoni. To address this question, we used a panel of blocking mAbs directed against different families of adhesion molecules and their counter-receptors, as potential inhibitors of ADCC. Competition experiments were also performed by testing the inhibitory effect of different soluble ligands.

We found that $\mathrm{mAbs}$ directed against the $\beta 2$ integrin Mac-1, against E-, L- and P-selectins and against $\mathrm{Le}^{\mathrm{X}}$ were able to significantly inhibit eosinophil-mediated cytotoxicity, when used at a final concentration of $10 \mu \mathrm{g} / \mathrm{ml}$, whereas the other tested mAbs had no inhibitory effects (Nutten et al. in preparation). Since mAbs were simultaneously added to effector cells and parasite targets, the observed effects could be due to blockade of adhesion molecules expressed by eosinophils and/or by schistosomes. To define more precisely the molecules engaged in eosinophil-schistosomulum interactions, the same mAbs were preincubated either with effector cells or with schistosomula, before contact between cells and parasites. Inhibition of cytotoxicity was detected after preincubation of eosinophils with mAbs directed against Lselectin and against the carbohydrate epitope $\mathrm{Le}^{\mathrm{X}}$. Moreover, preincubation of schistosomes with $\mathrm{mAbs}$ directed against $\mathrm{Le}^{\mathrm{X}}$ and against $\mathrm{P}$ - and $\mathrm{E}$ selectins, also significantly reduced parasite mortality. To confirm that selectin/carbohydrate interactions are involved in ADCC mediated by eosinophils, we performed competition experiments with soluble recombinant selectins and with $\mathrm{Le}^{\mathrm{X}}$ containing mucins. Compared to irrelevant lectins 
or mucins, this also resulted in a significant reduction of parasite mortality. Taken together, this suggests that selectins and carbohydrate ligands for selectins are crucial for the effector function of eosinophils towards schistosomula targets.

We noted that whatever inhibitory reagent used in ADCC inhibition assays (mAbs, recombinant proteins, mucins), no significant decrease of eosinophil-schistosomulum adherence levels was observed suggesting that the adhesion molecules involved in ADCC are implicated in cellular activation rather than in a simple adhesion. In respect to the recent demonstration that L-selectin can trigger intracellular signals (Brenner et al. 1996), we suggest for the first time that L-selectin can, in synergy with $\mathrm{FcR}$ and with other $\mathrm{Le}^{\mathrm{X}}$-bearing receptors (such as Mac-1), potentiate cytotoxic reactions of eosinophils to schistosomes (see the Fig.). We have recently extended these observations in another model of study using peritoneal rat macrophages as effector cells (Trottein et al. 1997).

\section{EXPRESSION OF ADHESION MOLECULES BY SCHIS- TOSOMES}

To confirm the presence of schistosomula receptors sharing common epitopes with mammalian selectins, immunolabelling experiments were performed on fixed schistosomula. Mabs directed against E-selectin highly labelled the surface of schistosomula obtained from cercariae by the skin penetration procedure. This labelling pattern appeared homogeneous and essentially located on the parasite surface. To ensure that surface expression of such molecules could not be only due to passive adsorption during skin penetration, similar experiments were performed with mechanically transformed schistosomula. The observed labelling was as intense as in the case of skin schistosomula but located just under the surface of the parasite and more dispersed. These observations are in favour of the parasitic origin of these molecules since the mechanically transformed schistosomula have never been in contact with the host.

Since carbohydrate structures similar to selectin ligands appear to be expressed by schistosomula, labelling experiments with biotinylated recombinant selectins were performed. Schistosomula showed surface labelling with biotinylated L- and P-selectins whereas E-selectin labelled parasites only slightly. The absence of parasite labelling in the presence of EGTA (a calcium chelator) confirmed the calcium dependency of selectin binding to parasite surface (Trottein et al. 1997). The presence of $\mathrm{Le}^{\mathrm{X}}$ on schistosomes had already been described (Ko et al. 1990, Srivastan et al. 1992, Köster \& Strand 1994) but no precise function was reported so far excepted a putative role in T-helper type 2 orientation in $S$. mansoni-infected animal models (Velupillai et al. 1994). On the other hand, the demonstration that schistosomula can express a molecule cross-reacting with the mammalian selectins, a so-called "selectin-like" molecule, is totally original. Not only such molecule is present on the parasite surface but also appears to exert a
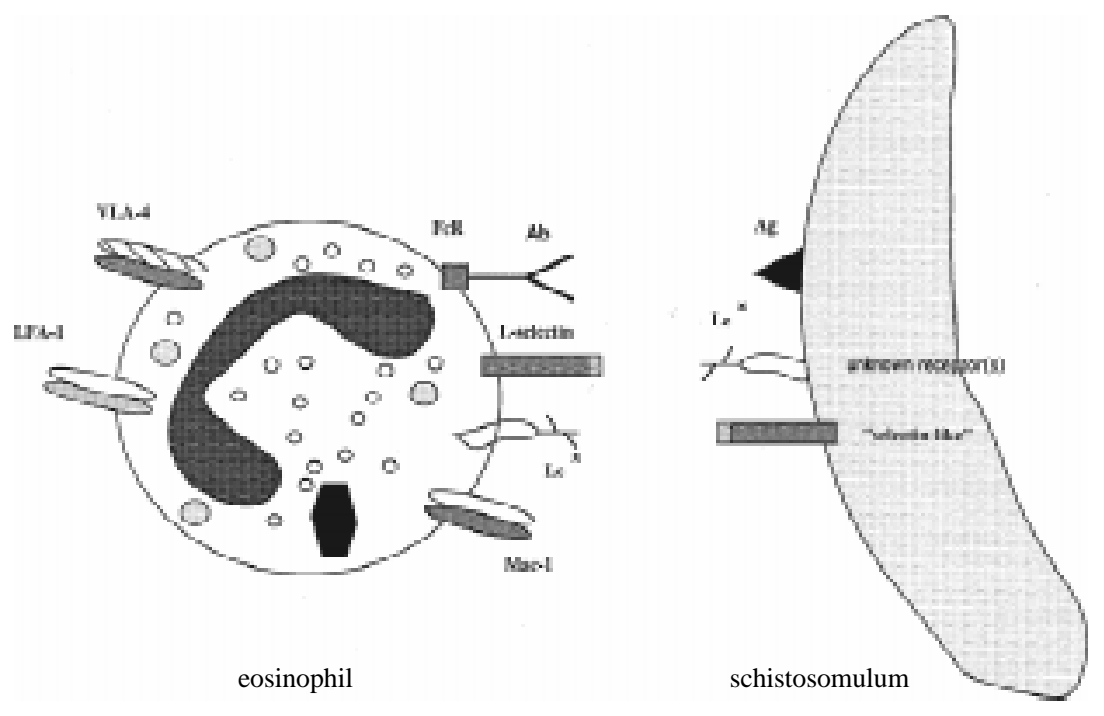

Hypothetical model of eosinophil-schistosomulum interactions during antibody-dependent cell-mediated cytotoxicity. The interaction of effector cell to parasite target is specifically mediated by the FcR/Ab/Ag complex whilst co-stimulation appears to require a double selectin-Le ${ }^{X}$ interaction between eosinophil and schistosomulum. Since the carbohydrate determinant Le ${ }^{X}$ can be associated with Mac-1 and/or with L-selectin, it is likely that activation of eosinophils through Le ${ }^{X}$ is linked to Mac-1 and L-selectin signal transduction effects. The size of the eosinophil (8-12 $\mu)$ has not been respected compared to the size of the depicted schistosomulum $(150-250 \mu)$. 
signaling role to host cells. The in vivo relevance of selectin-Le ${ }^{\mathrm{X}}$ interactions between host cells and schistosomes is currently investigated.

Similarly to lymphoid cell populations, eosinophils seem to require several membrane receptors in order to exert their cytotoxic properties. Not only specific IgE receptors both of low and high affinity are involved but also members of the adhesion molecule family. The precise role of the latter molecules in eosinophil activation has still to be demonstrated. However, the present studies on eosinophil and schistosome interactions has led to new functions for these adhesion molecules.

Proverbially associated with helminthic infections, eosinophils appear more and more on the light of recent findings not as bystander cells but as key actors of the host parasite interplay. Their refined equipment in terms of receptors and adhesion molecules together with their amazing ability to produce a large variety of intercellular signals argue for their active role as effector and regulatory cells in immune responses both in parasitic and allergic diseases.

\section{REFERENCES}

Bevilacqua MP, Nelson RM 1993. Endothelial-leukocyte adhesion molecules in inflammation and metastasis. Thromb Haemost 70 : 152-165.

Bochner BS, Sterbinsky SA, Bickel CA, Werfel S, Wein M, Newman W 1994. Differences between human eosinophils and neutrophils in the function and expression of sialic acid-containing counterligands for E-Selectin. J Immunol 152 : 774-782.

Brenner B, Gulbins E, Schlottmann K, Koppenhoefer U, Busch GL, Walzog B, Steinhausen M, Coggeshall KM, Linderkamp O, Lang F 1996. L-selectin activates the Ras pathway via the tyrosine kinase $\mathrm{p} 56^{\mathrm{lck}}$. Proc Natl Acad Sci USA 93: 15376-15381.

Butterworth AE, Vadas MA, Wassom DL, Dessein A, Hogan M, Sherry B, Gleich GJ, David JR 1979. Interactions between human eosinophils and schistosomula of Schistosoma mansoni. II. The mechanism of irreversible adherence. J Exp Med 150: 1456-1471.

Capron A, Dessaint JP, Capron M, Joseph M, Ameisen JC, Tonnel AB 1986. From parasites to allergy: a second receptor for IgE. Immunol Today 7: 15-18.

Capron M, Capron A, Dessaint JP, Torpier G, Johansson G, Prin L 1981. Fc receptors for IgE on human and rat eosinophils. J Immunol 126: 2087-2092.

Capron M, Jouault T, Prin L, Joseph M, Ameisen JC, Butterworth AE, Papin JP, Kusnierz JP, Capron A 1986. Functional study of a monoclonal antibody to $\mathrm{IgE} \mathrm{Fc}$ receptor (Fc epsilon RII) of eosinophils, platelets and macrophages. J Exp Med 164: 72-89.

Capron M, Spiegelberg HL, Prin L, Bennich H, Butterworth AE, Pierce RH, Ouaissi MA, Capron A 1984. Role of IgE receptors in effector function of human eosinophils. J Immunol 132: 462-468.

Capron M, Truong MJ, Aldebert D, Gruart V, Suemura
M, Delespesse G, Tourvieille B, Capron A 1991. Heterogenous expression of CD23 epitopes by eosinophils from patients. Relationships with IgE mediated functions. Eur J Immunol 21: 2423-2429.

Carlos TM, Harlan JM 1994. Leukocyte-endothelial adhesion molecules. Blood 84: 2068-2101.

Foxall C, Watson SR, Dowbenko D, Fennie C, Lasky LA, Kiso M, Masegawa A, Asa D, Brandley BK 1992. The three members of the selectin receptor family recognize a common carbohydrate epitope, the sialyl Lewis ${ }^{\mathrm{X}}$ oligosaccharide. J Cell Biol 117: 895-902.

Grangette C, Gruart V, Ouaissi MA, Rivzi F, Delespesse G, Capron A, Capron M 1989. IgE receptor on human eosinophils (FceRII). Comparison with B cell CD23 and association with an adhesion molecule. $J$ Immunol 143: 3580-3588.

Jouault T, Capron M, Balloul JM, Ameisen JC, Capron A 1988. Quantitative and qualitative analysis of the $\mathrm{Fc}$ receptor for IgE (Fc epsilon RII) on human eosinophils. Eur J Immunol 18: 237-241.

Kansas GS 1996. Selectins and their ligands: current concepts and controversies. Blood 88: 3259-3287.

Ko AI, Dräger, UC, Harn DA 1990. A Schistosoma mansoni epitope recognized by a protective monoclonal antibody is identical to the stage-specific embryonic antigen 1. Proc Natl Acad Sci USA 87: 4159-4163.

Köster B, Strand M 1994. Schistosoma mansoni: immunolocalization of two different fucose-containing carbohydrate epitopes. Parasitology 108: 433446.

Larsen E, Palabrica T, Sajer S, Gilbert GE, Wagner DD, Furie BC, Furie B 1990. PADGEM-dependent adhesion of platelets to monocytes and neutrophils is mediated by a lineage-specific carbohydrate, LNF III (CD15). Cell 63: 467-474.

Lasky LA 1992. Selectins: interpreters of cell-specific carbohydrate information during inflammation. Science 258: 964-969.

Ravetch JV, Kinet JP 1991. Fc receptors. Annu Rev Immunol 9: 457-492

Rosen SD, Bertozzi CR 1994. The selectins and their ligands. Cur Opin Cell Biol 6: 663-673.

Schleimer RP, Sterbinsky SA, Kaiser J, Bickel CA, Klunk DA, Tomioka K, Newman W, Luscinkas FW, Grimbrone MA, McIntyre BW, Bochner BS 1992. IL-4 induces adherence of human eosinophils and basophils but not neutrophils to endothelium. Association with expression of VCAM-1. J Immunol 148: 1086-1092.

Soussi Gounni A, Lamkhioued B, Ochiai K, Tanaka Y, Delaporte E, Capron A, Capron M 1994. High affinity $\mathrm{IgE}$ receptor on eosinophils is involved in defence against parasites. Nature 367: 183-186.

Springer TA 1990. Adhesion receptors of the immune system. Nature 346: 425-434.

Srivastan J, Smith DF, Cummings RD 1992. The human blood fluke Schistosoma mansoni synthetizes glycoproteins containing the Lewis $\mathrm{X}$ antigen. J Biol Chem 267: 20196-20203.

Tomassini M, Tsicopoulos A, Tai PC, Gruart V, Tonnel 
AB, Prin L, Capron M, Capron A 1991. Release of granule proteins by eosinophils from allergic and nonallergic patients with eosinophilia on immunoglobulin-dependent activation. J Allergy Clin Immunol 88: 365-375.

Trottein F, Nutten, S, Papin, JP, Leportier C, PoulainGodefroy O, Capron A, Capron M 1997. Role of adhesion molecules of the selectin-carbohydrate families in antibody-dependent cell-mediated cytotoxicity to schistosome targets. J. Immunol 159: 804811.

Truong MJ, Gruart V, Liu FT, Prin L, Capron A, Capron M 1993. Human eosinophils express functional IgE binding molecules (mac 2/epsilon BP) of the S-type lectin family. Eur J Immunol 23: 3230-3235.
Velupillai P, Harn DA 1994. Oligosaccharide-specific induction of interleukin 10 production by $\mathrm{B} 220^{+}$cells from schistosome-infected mice: a mechanism for regulation of CD4 ${ }^{+}$T-cell subsets. Proc Natl Acad Sci USA 91: 18-22

Wang B, Rieger A, Kilgus O, Ochiai K, Maurer D, Födinger D, Kinet JP, Stingl G 1992. Epidermal Langerhans cells from normal human skin bind monomeric IgE via Fc epsilon RI. J Exp Med 175: 1353-1365.

Yokota A, Kikutani H, Tanaka T, Sato R, Barsumian EL, Suemura M, Kishimoto T 1988. Two species of human FceR receptor II (FcعRII/CD23): Tissue-specific and IL4-specific regulation of gene expression. Cell 55 : 611-618. 